\title{
Using sentinel cages to estimate infestation pressure on salmonids from sea lice in Loch Shieldaig, Scotland
}

\author{
Campbell C. Pert ${ }^{1, *}$, Rob J. Fryer ${ }^{1}$, Paul Cook ${ }^{1}$, Rachel Kilburn ${ }^{1}$, Sonia McBeath ${ }^{1}$, \\ Alastair McBeath ${ }^{1}$, Iveta Matejusova ${ }^{1}$, Katy Urquhart ${ }^{1}$, Sarah J. Weir ${ }^{1}$, \\ Una McCarthy ${ }^{1}$, Catherine Collins ${ }^{1}$, Trish Amundrud ${ }^{1}$, Ian R. Bricknell ${ }^{1,2}$ \\ ${ }^{1}$ Marine Scotland Science, Marine Laboratory, PO Box 101, 375 Victoria Road, Aberdeen, Scotland AB11 9DB, UK \\ ${ }^{2}$ School of Marine Sciences, University of Maine, 5735 Hitchner Hall, Orono, Maine 04469-5735, USA
}

\begin{abstract}
Sentinel Atlantic salmon, held in cages, were used to estimate the monthly infestation pressure of sea lice at 3 locations along a salmonid migration route in Loch Shieldaig, a Scottish west coast sea loch. The study lasted $30 \mathrm{mo}$, covering an entire production cycle and fallow period at nearby fish farms. A total of 5007 sea lice were sampled from 3097 sentinel fish, with over $99 \%$ of these being Lepeophtheirus salmonis. Infestation pressure was higher in cages nearer the head of the loch and the River Shieldaig estuary. Copepodids were the main infective life cycle stage, but a few ( $0.5 \%$ of total lice sampled) mobile pre-adult and adult stages were also found on the sentinel fish. Infestation pressure on the sentinel fish was correlated with gravid L. salmonis counts from nearby farms. However, there was no evidence that particular events, such as treatments, at the farms led directly to changes in infestation pressure. These findings suggest that, although aquaculture is a contributor of sea lice larvae into the Torridon system, further work is required to determine factors influencing the relationship between farm sea lice levels and infestation pressure in the wider environment.
\end{abstract}

KEY WORDS: Lepeophtheirus salmonis - Sea lice - Infestation pressure - Sentinel cages · Aquaculture $\cdot$ Sea loch $\cdot$ Infectious copepodid

\section{INTRODUCTION}

Sea lice are ectoparasitic crustaceans often found infesting salmonids in the Northern Hemisphere (Kabata 2003). In Scotland, the 2 main species that infest wild and farmed salmonids are Lepeophtheirus salmonis (Krøyer, 1837) and Caligus elongatus von Nordmann, 1832 (Pike \& Wadsworth 1999). Their life cycles include 2 larval naupliar stages, an infective copepodid stage, 4 attached intermediate chalimus stages (recently considered to be 2 chalimi stages with male and female displaying differences; Hamre et al. 2013) and a mobile adult stage for $C$. elongatus

${ }^{*}$ Corresponding author: campbell.pert@scotland.gsi.gov.uk
(Piasecki 1996) and 2 pre-adult and adult mobile stages for L. salmonis (Schram 1993). The nauplius I and II stages of $L$. salmonis and $C$. elongatus are nonfeeding and rely on internal reserves for nutrients during their development within the water column to the infective copepodid stage (Pike \& Wadsworth 1999). Transmission to the host is mainly dependent on the copepodid stage, which, similar to many parasitic copepod free-living stages, is time-limited by its stored energy supplies (Pike \& Wadsworth 1999). However, infestations could potentially be initiated by pre-adults and adults, which have been shown to actively transfer between hosts in laboratory trials

() The Crown 2014. Open Access under Creative Commons by Attribution Licence. Use, distribution and reproduction are unrestricted. Authors and original publication must be credited. 
(Bruno \& Stone 1990, Ritchie 1997, Hull et al. 1998). Of the 2 species, L. salmonis is more usually associated with infestations on farmed Atlantic salmon Salmo salar L., which can result in mechanical damage to the skin, osmoregulatory stress and secondary infections (Ritchie 1997, Finstad et al. 2000). Severe infestations, if left untreated, can lead to large losses of cultured stock, particularly of Atlantic salmon post-smolts (Pike \& Wadsworth 1999, Johnson et al. 2004). The annual cost to the Scottish aquaculture industry from sea lice infestations through treatments, associated labour costs and mortalities has been estimated to be around £29 million (Costello 2009).

Potential interactions between sea lice and wild and farmed salmonids have increased with the development of intensive marine salmonid farming around Scotland's west coast and islands (Pike \& Wadsworth 1999, Johnson et al. 2004). A study by Penston \& Davies (2009) found that numbers of gravid females on fish farms correlated with the numbers of copepodids in surrounding waters. An increase in sea lice abundance has been linked to an increase in marine mortality of migratory salmonids, and marine salmon farming activities on Scotland's west coast have been implicated as an important contributory factor (Butler 2002, Penston et al. 2004, Vøllestad et al. 2009, Middlemas et al. 2010, Middlemas \& Armstrong 2012).

The survival, dispersal and infectivity of sea lice larvae, in common with other marine planktonic larvae, depends on factors such as predator avoidance, wind direction, currents, transportation, water temperature, salinity and food availability (Wootten et al. 1982, Heuch \& Karlsen 1997, Johnson \& Albright 1991, Boxaspen \& Naess 2000, Bricknell et al. 2006, Amundrud \& Murray 2009, Losos et al. 2010). There have been many studies investigating the development time of Lepeophtheirus salmonis from the egg to the copepodid stage (Johannessen 1978, Wootten et al. 1982, Johnson \& Albright 1991, Boxaspen \& Naess 2000, Stien et al. 2005). Lower water temperatures increase the developmental time before moulting to the copepodid stage (Pike \& Wadsworth 1999, Stien et al. 2005), thus increasing the risk of predation (Losos et al. 2010). Water temperature also affects the rate at which energy reserves are used up by copepodids (Wootten et al. 1982) and adults (Johnson \& Albright 1991), which in turn affects the period of infectivity. Exposure to salinities $<29$ for $1 \mathrm{~h}$ reduced both the survival and infectivity of $L$. salmonis copepodids hatched out from egg strings collected from Scottish west coast aquaculture sites (Bricknell et al. 2006). In other studies, salinities $<25$ prevented development to the copepodid stage under laboratory conditions (Johnson \& Albright 1991), whereas L. salmonis copepodids were shown to survive at salinities < 20 in Norway (Bengtsen et al. 2012).

Estimating the numbers of sea lice available to infest wild salmonids, and how these vary spatially and temporally, is a considerable challenge. Abundance estimates from spot samples with plankton nets and pumps are indicative, but are notoriously variable (Gaines \& Bertness 1993, Moksnes \& Wennhage 2001, Penston et al. 2004, 2008a,b, Penston \& Davies 2009), and fail to consider the viability and settlement rates of the lice and how these might vary for larvae from different physical environments (Johnson \& Albright 1991, Bricknell et al. 2006).

A better way of measuring numbers of viable planktonic larvae is to provide the larvae with a suitable habitat for settlement (Moksnes \& Wennhage 2001). As Lepeophtheirus salmonis are largely specific to salmonid hosts, the use of Atlantic salmon in sentinel cages should provide a natural settlement opportunity for the larvae within the water column (Pike \& Wadsworth 1999), with observed settlement levels being a measure of sea lice infestation at the cage location integrated over the deployment period. Sentinel fish have been used to investigate the presence and settlement of parasites such as the monogenean Benedenia seriolae (Chambers \& Ernst 2005) and the myxosporean Myxobolus cerebralis (Sollid et al. 2004). Sentinel Atlantic salmon smolts have been used to estimate sea lice settlement in salmon farming areas of Ireland, Norway and Scotland (Tully 1989, McVicar et al. 1993, Costelloe et al. 1995, Finstad 2007). For example, 15 cages containing Atlantic salmon were used to estimate settlement levels along almost the entire length of Hardangerfjord in Norway (Finstad 2007). However, all these studies of sea lice settlement exposed the sentinel fish for periods exceeding the generation time for L. salmonis, and so they could not determine whether the fish had initially become infected by copepodids or later preadult and adult stages directly, or if individuals developed to pre-adult and adult stages on the fish. Therefore, the contribution of the different sea lice stages to the primary infestations could not be established conclusively. Sentinel cages are used to investigate the infestation pressure on wild salmonids at fixed locations and timepoints within the aquatic environment. A period in the wild salmonid life cycle when information on infestation pressure may be especially important is during the smolt migration, when the fish are potentially more vulnerable to lice 
infestation due to their small size, have a lower host response to the parasite, and may encounter elevated lice levels in inshore waters (Tully \& Whelan 1993, Pike \& Wadsworth 1999, Pert et al. 2009).

The present study placed sentinel hatchery-reared Atlantic salmon into cages at locations increasingly distant from the River Shieldaig estuary, in Loch Shieldaig, Scotland, along a salmonid migration route. The cages were deployed for $1 \mathrm{wk}$ each month over a 30 mo period, which covered a full production cycle and fallow period in nearby fish farms. The sentinel salmon were used to quantify the infestation pressure (defined as the number of settled lice per unit volume of water flowing through the cage, corrected for fish size) along the migration route and how this changed over the farm production cycle. The study also investigated the population structure of the settled sea lice and how this varied with time.

\section{MATERIALS AND METHODS}

\section{Study area}

The study was conducted in Loch Shieldaig (Fig. 1) on the west coast of Scotland. Loch Shieldaig is part of the Loch Torridon system, which also includes Upper Loch Torridon and Loch Torridon. Loch Shieldaig was selected because it is relatively small, contains 2 Atlantic salmon farms (consented biomasses

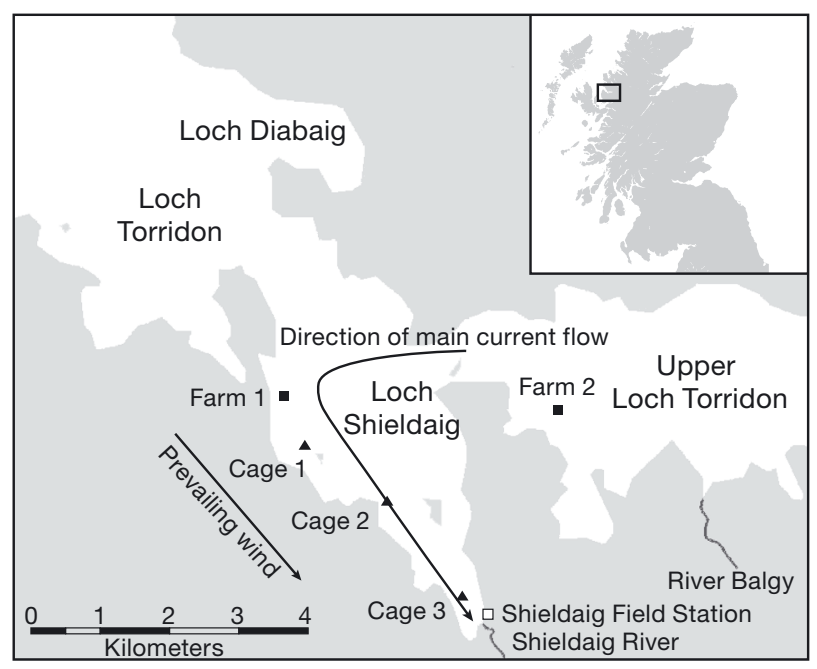

Fig. 1. Loch Shieldaig study site, with sentinel cage (Cages 1, 2 and 3) locations, prevailing wind, main current from Upper Loch Torridon under prevailing wind conditions, main local rivers, Marine Scotland-Science (MSS) Shieldaig Field Station, and marine aquaculture sites (Farms 1 and 2) marked. Inset: location of study site in Scotland, UK of 1375 and $976 \mathrm{t}$ for Farms 1 and 2, respectively) and has been used extensively to study sea lice and their interactions with wild salmonids (McKibben \& Hay 2004, Penston et al. 2004, 2008a,b, Amundrud \& Murray 2009, Penston \& Davies 2009, Pert et al. 2009, Middlemas et al. 2010). The 2 main rivers that flow into the loch system are the Balgy and Shieldaig, which support salmonid populations dominated by Atlantic salmon and sea trout Salmo trutta L., respectively. The Torridon system is part of a region affected by sea-trout stock collapses (Butler 2002, Anonymous 2009, Penston \& Davies 2009, Middlemas et al. 2010), with annual captures of less than 100 salmon and sea trout in the Balgy and Shieldaig combined between 2003 and 2005 (Penston et al. 2008b).

Planktonic sea lice, mostly Lepeophtheirus salmonis, are found in the Loch Torridon system, in both river estuaries and open water (McKibben \& Hay 2004, Penston et al. 2004, 2008a,b). In open water, nauplii L. salmonis have been found in greater densities near the farms (Penston et al. 2008a). A 3-dimensional hydrographic model coupled with a biophysical particle tracking model was developed by Amundrud \& Murray (2009) to predict sea lice dispersal within the system. The model indicated that localised wind conditions were the dominant influence in lice dispersion patterns. Under the prevailing northwesterly wind, the model predicted high particle concentrations near the Shieldaig River estuary.

\section{Sentinel fish and cages}

Atlantic salmon were purchased in 3 batches during the study as unvaccinated parr from a commercial salmon hatchery in the Loch Torridon Area Management Agreement (AMA) zone. Holding, ongrowing and smoltification took place in the quarantine unit at the Marine Scotland Science, Fish Cultivation Unit, Aultbea, Scotland (since closed) to ensure the health status of the sentinel fish before transport into the Loch Torridon AMA. The salmon were smolted after $1 \mathrm{yr}$ (S1s) and held in $1 \mathrm{~m}$ circular fibreglass tanks with a tank volume of 3701 and a flow rate of approximately $101 \mathrm{~min}^{-1}$. Fish were maintained on 3-4 $\mathrm{mm}$ commercial pellets (Skretting) and fed $2 \%$ bodyweight $\mathrm{d}^{-1}$.

The sentinel cages were cylindrical $(1.5 \mathrm{~m}$ in diameter $\times 2 \mathrm{~m}$ height). Each cage was supported by 3 rings made of polyethylene pipe (38 $\mathrm{mm}$ inside diameter $\times 51 \mathrm{~mm}$ outside diameter) covered with $13 \mathrm{~mm}$ knotless mesh netting. The cage rings had $10 \mathrm{~mm}$ holes drilled at regular intervals to allow 
water in and out of the inner pipe, which also housed trawl wire for weight to ensure the cage sank when deployed. The tension in the net was maintained by a $7 \mathrm{~kg}$ weight hung from a bridle under the cage.

Three sentinel cages, each containing 50 Atlantic salmon, were deployed in the surface $3 \mathrm{~m}$ for $1 \mathrm{wk}$ each month from April 2006 to September 2008. The $1 \mathrm{wk}$ exposure time allowed the population structure of the settled sea lice to be inferred. One week is too short a time for Lepeophtheirus salmonis (Johnson \& Albright 1991) and Caligus elongatus (Piasecki \& MacKinnon 1995) to complete their life cycle, so any mobile stages found would have been transported to the sentinel fish rather than have developed from a resident lice population.

At the end of each deployment, all the fish were removed and euthanised using ethyl 3-aminobenzoate methanesulfonate salt (MS222; Sigma-Aldrich) at a dose of $1 \mathrm{~g} \mathrm{l}^{-1}$. A high dose of MS222 was used to euthanise the fish quickly and to minimise the loss of attached and mobile lice stages by contact with the sides of the anaesthesia tank. Once euthanised, each fish was removed from the anaesthetic, placed individually inside a clear plastic bag and put, with frozen ice packs, into an insulated box marked with the appropriate cage number and transported to the Marine Laboratory in Aberdeen for examination. The plastic bag and euthanasia water were examined for lice that may have become detached from the fish during handling and anaesthesia, although any lice in the euthanasia water could only be attributed to a cage, not to an individual fish.

All fish were measured and weighed before the external surface of each fish was visually assessed. Lice numbers, developmental stage and location on the host were noted, with an initial species identification made as described by Johnson \& Albright (1991) and Schram (1993). A subsample of at least 1 louse per infested fish was collected and pooled by cage for real-time PCR species identification as described by McBeath et al. (2006).

The 30 mo study covered an entire production cycle on the nearby fish farms, which stocked with fish in April 2006, became fallow by December 2007 (Farm 1) and February 2008 (Farm 2), and restocked in April 2008. The cages were placed in Loch Shieldaig at increasing distances from the River Shieldaig estuary along one of the main salmonid migration routes (Fig. 1). The fish were size-matched as closely as possible every month over the 30 mo of the study, subject to fish availability, with the monthly median length and weight ranging from 165 to $333 \mathrm{~mm}$ and 64 to $430 \mathrm{~g}$, respectively.

\section{Lice counts on farmed fish}

Monthly mean numbers of gravid lice per fish at each farm were calculated from data supplied by the companies operating in the Loch Torridon system via the Loch Torridon Area Management Group. Lice counts from the farms were collected in accordance with the Industry Code of Good Practise (CoGP) (Anonymous 2006), which stipulates that when there are more than 5 pens per site (as in this case), 5 fish must be sampled from each of 5 pens ( 25 fish in total) each week. The monthly numbers of salmon on each farm were not supplied, so the lice densities could not be converted into lice burdens. Sea lice treatments were carried out at both farms during the study period.

\section{Environmental data}

Valeport 106 current meters recorded water flow and pressure at each cage at 5 min intervals. Salinity and temperature were recorded at $10 \mathrm{~min}$ intervals using conductivity-temperature-pressure miniloggers (Star-Oddi). The current meters and miniloggers were suspended $1 \mathrm{~m}$ below the cages (about $4 \mathrm{~m}$ below the surface), with swivels allowing free rotation of the current meters. Equipment was not placed within the cages to avoid damaging the fish. Before the study, mini-loggers deployed within the cages (about $2 \mathrm{~m}$ below the surface) gave similar results to those below the cages, indicating that the salinity and temperature measurements are likely to have been representative of conditions inside the cages. There is limited freshwater input to the Loch Torridon system, except during heavy sustained rainfall. Stage data from the Shieldaig River, provided by the Scottish Environmental Protection Agency (SEPA), were used to identify any major freshwater inputs during the study that may have reduced salinity near the cages.

The volume of water that passed through each cage was calculated from the mean flow scaled to correspond to $1 \mathrm{wk}$ and $3 \mathrm{~m}^{2}$ (the area obtained by taking a slice down the middle of the cage). The current-meter records contained segments with zero flow, which was unsurprising, as the lower range of the meters was $0.03 \mathrm{~m} \mathrm{~s}^{-1}$ and the cages were in areas of low flow (Gillibrand \& Amundrud 2007). However, some records had long periods of zero flows, suggesting instrument malfunction, and these periods were excluded when calculating mean flow. 


\section{Data analysis}

The relationship between the lice counts on the sentinel fish and the explanatory variables cage, month (from the start of the experiment) and fish length was investigated using generalised linear mixed models (McCulloch \& Searle 2001), assuming negative binomial errors and a log link. The main effects of cage, month (both treated as categorical variables) and log fish length were included as fixed effects. The interaction between cage and month was included as a random effect, allowing for random variation in abundance between cages within months in addition to the fixed cage effect. The choice of random effects was based on preliminary modelling that showed that the interaction between cage and month was the only significant interaction among the 3 explanatory variables, but found no structure to this interaction. Differences in flow were accounted for by including the log volume of water that passed through the cage as an offset variable. Parameter estimates are interpreted as the number of attached lice per litre of water that passed through the cage. The significance of the fixed effects was assessed by Wald tests, supplemented by pairwise comparisons with $\mathrm{p}$-values corrected for the number of comparisons using a sequentially rejective Bonferroni procedure (Holm 1979).

The relationship between the counts of lice on the sentinel fish and the counts of gravid lice from the 2 salmon farms was investigated by estimating the cross-correlation between the time series at a series of time lags (Diggle 1990). The lice counts on the sentinel fish were summarised by the month effects estimated from the generalised linear mixed model, as these were adjusted for differences in fish length, cage and flow. The lice counts on the farmed fish were summarised by the mean number of gravid lice per fish each month. Spearman correlations were used to avoid making parametric assumptions about the data. The cross-correlations were computed on both the untransformed data and on the data de-trended by taking a 4th-root transform, fitting a loess smoother and extracting the residuals. The analysis of the untransformed data leads to inferences about the broad association between the lice counts on the farmed and sentinel fish. However, to formally attribute changes in counts on the sentinel fish to changes in counts on the farms, it is necessary to analyse the de-trended data, since then the effect of variables that affect both time series (e.g. seasonal patterns) has been removed (Diggle 1990).

\section{RESULTS}

Over the 30 mo study, a total of 5007 sea lice were sampled from 3097 sentinel fish. The total numbers of lice recorded from each cage were 1333 from Cage 1, 1515 from Cage 2 and 2159 from Cage 3. All the sea lice were identified as Lepeophtheirus salmonis $(99.8 \%)$, except for 1 pool of 8 individuals from Cage 3 in April 2007 that tested positive by quantitative PCR (qPCR) for both L. salmonis and Caligus elongatus. The median volume of water passing through the cages was 116000,91000 and $53000 \mathrm{~m}^{3}$ for Cages 1 to 3, respectively (overall range: 22000 to $189000 \mathrm{~m}^{3}$ ). Salinity at the cages never fell below 29. Stage data from the Shieldaig River showed no extreme inputs of freshwater to the loch system in 2007 and 2008, so low salinity is unlikely to have reduced lice infectivity near the cages (Bricknell et al. 2006). Mean monthly water temperatures (range over the study: 7.8 to $13.7^{\circ} \mathrm{C}$ ) showed a strong annual cycle, but differences between cages in any one month were no more than $0.1^{\circ} \mathrm{C}$.

The larval copepodid and early chalimus stages were most abundant (Fig. 2), with only 12 pre-adults and 12 adults recorded, which represents $\sim 0.5 \%$ of the infestive lice found during the study.

The mean lice counts (all stages) on the sentinel fish are shown in Fig. 3 by cage and month. There were no data for a few deployments due to predation and damage, but there were always counts for at least 1 cage each month. Lice counts were low from April 2006 through to December 2006 (mean: $\leq 0.5$ lice fish $^{-1}$ in all cages), began to rise in January 2007 , peaked in July and August 2007 (largest mean of 15.1 lice fish ${ }^{-1}$ in Cage 3 in July 2007), then declined rapidly and were low from November 2007 through to September 2008 (mean: $\leq 0.5$ lice fish $^{-1}$ in all cages).

Cage location, month and fish length all had a significant effect on lice counts on the sentinel fish $(\mathrm{p}<$ 0.0001 in all cases). The effects of cage location and month are illustrated in Fig. 4. Having adjusted for flow, the fish in Cage 3 had $157 \%$ more lice than those in Cage 2 (95\% [CI]: 81 to $266 \%$; p < 0.0001), and the fish in Cage 2 had $52 \%$ more lice than those in Cage 1 (95\% CI: 2 to $126 \%$; $=0.036)$. Lice counts increased with fish length, with the coefficient of the relationship estimated to be 1.86 (95\% CI: 1.46 to 2.26), so lice counts were proportional to fish surface area (O'Shea et al. 2006).

The gravid lice counts at the fish farms showed a similar trend to the lice counts on the sentinel fish, with counts beginning to increase in November 2006, peaking in late summer 2007, and declining by 


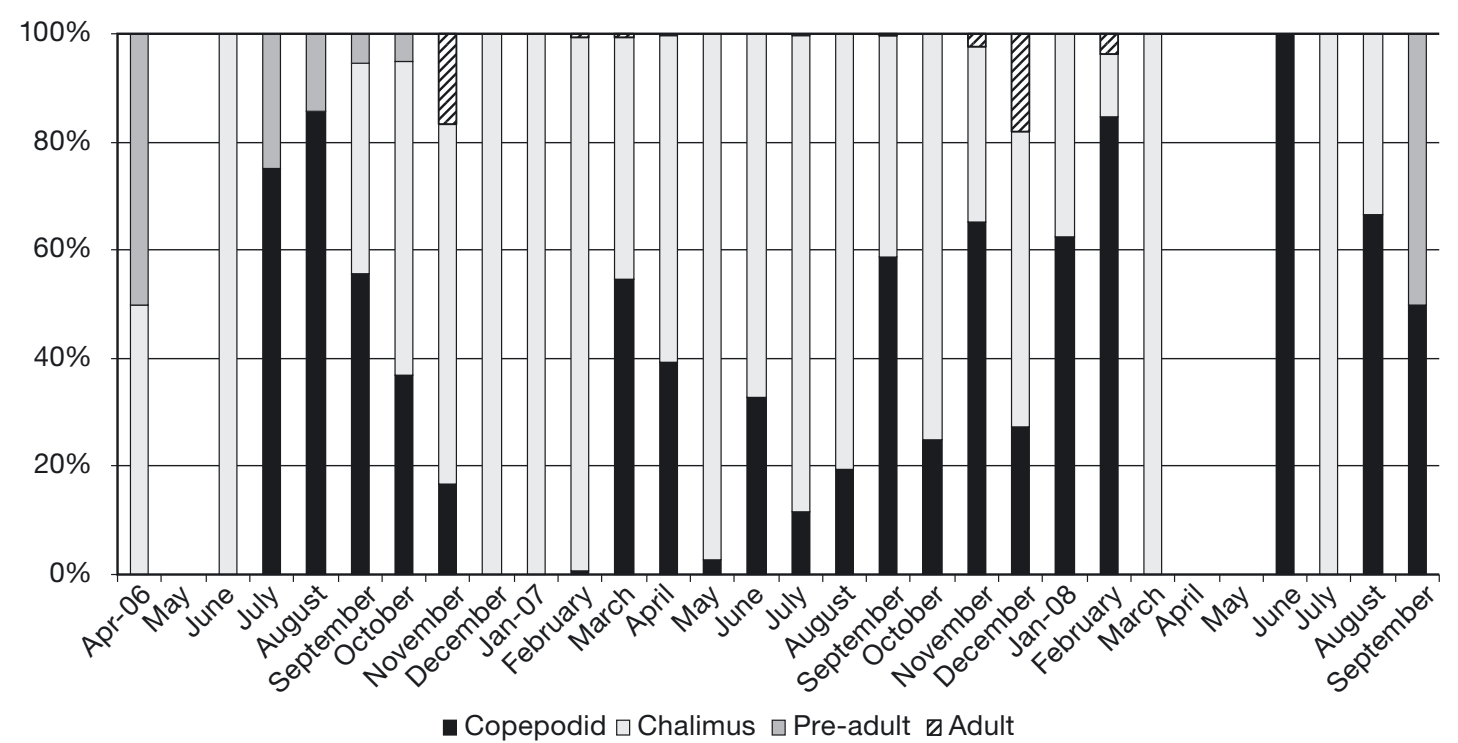

Fig. 2. Monthly breakdown of life cycle stages of sea lice on the sentinel fish from April 2006 to September 2008

December 2007 (Fig. 3). The sentinel counts were positively correlated with the untransformed counts at the 2 farms at a wide range of time lags (pointwise $5 \%$ significance level) (Fig. 5). The de-trended data showed 3 lags, with correlations close to the $5 \%$ pointwise significance level (Fig. 5). However, as 2 of these correlations are negative, and thus difficult to explain biologically, and as no adjustments have been made for the number of comparisons, we infer that there is no strong evidence of any relationship between the de-trended time series.
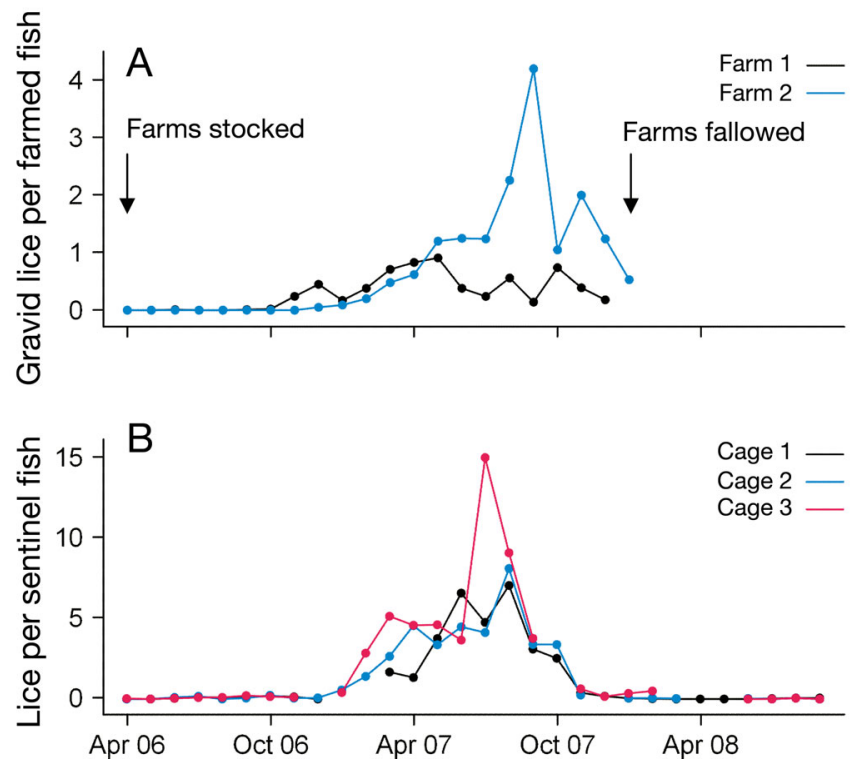

Fig. 3. Summary of sea lice counts from April 2006 to September 2008. (A) Mean number of gravid lice on each farmed fish by farm and month, and (B) mean number of lice (all stages) on each sentinel fish by cage and month
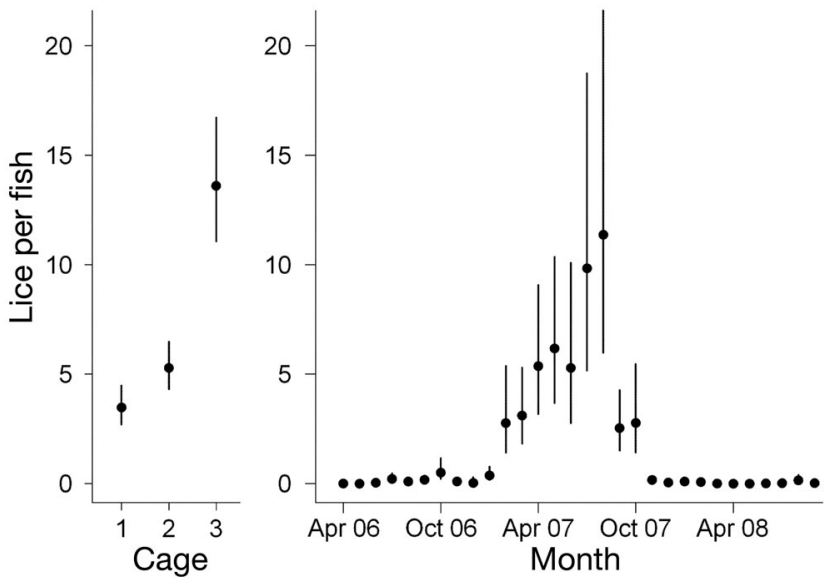

Fig. 4. Cage and month effects on sea lice (all stages) counts from the sentinel fish. Dots are the estimated effects, and vertical lines are pointwise $95 \%$ confidence limits. For interpretability, cage effects are standardised to June 2007, fish length of $235 \mathrm{~mm}$ (median length of the sentinel fish), and water volume of $10^{5} \mathrm{~m}^{3}$ (close to the median volume), while the month effects are standardised to Cage 2, fish length of $235 \mathrm{~mm}$, and volume of $10^{5} \mathrm{~m}^{3}$

\section{DISCUSSION}

This study provides the first estimates of sea lice infestation pressure on wild salmonids in a Scottish sea loch at specific sites, at monthly intervals over a period covering a full salmon production cycle and a fallow period at 2 farms occupying the same loch. Previous studies in the Loch Torridon system have estimated sea lice larval densities from plankton tows (Penston et al. 2004, 2008a,b, 2011). However, these 


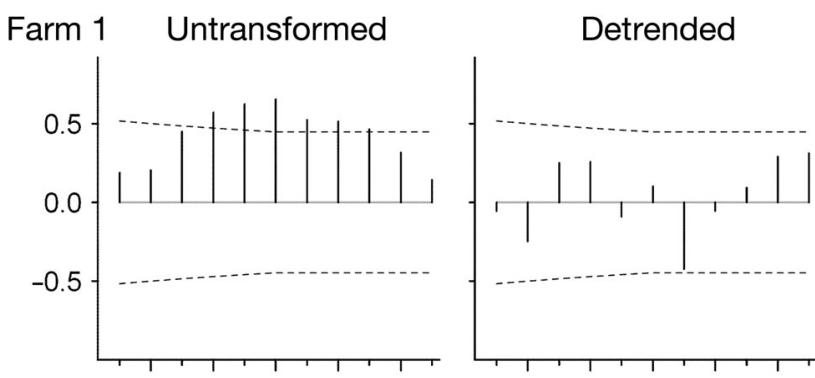

Farm 2

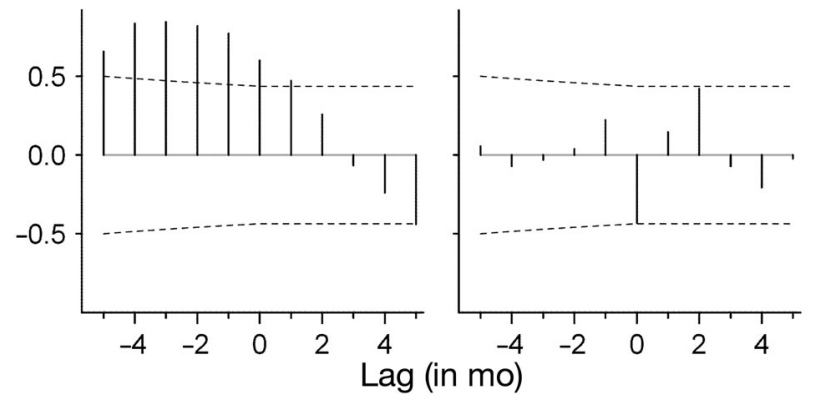

Fig. 5. Cross-correlations (thick vertical lines) between sea lice (all stages) abundance on the sentinel fish and on the fish from 2 farms using both untransformed and de-trended data. The cross-correlation at lag zero is the correlation between counts in the sentinel cages and the farms in the same month; the cross-correlation at a lag of 1 mo is the correlation between counts in the sentinel cages and the farms 1 mo before; and so on. Correlations outside the dashed reference lines are significant at the pointwise $5 \%$ level

are likely to overestimate infestation pressure, as not all the sampled lice will be viable. For example, the total number of settled lice in any one cage never exceeded 0.02 lice $\mathrm{m}^{-3}$ over the week-long exposure period, about 100 -fold lower than the mean density of Lepeophtheirus salmonis larvae found in plankton tows collected at 2 nearby sample stations, though often in different weeks of the same month (Penston et al. 2011). Moksnes \& Wennhage (2001) also found lower numbers of decapod larvae on artificial settlement substrates than in plankton net samples, and proposed that the nets collected high numbers of non-viable larvae. In other studies, sentinel fish have had lower lice burdens than fish from the same area caught by trawling or gill-netting, suggesting that sentinel fish underestimate infestation pressure (Bjørn et al. 2011). However, the other capture methods have no control over exposure history, either temporally or spatially, so provide a different metric of infestation pressure.

The estimates of infestation pressure reported here only apply to the surface waters to about $3 \mathrm{~m}$, the depth of the sentinel cages. However, these are likely to be reasonable estimates of the infestation pressure on wild salmonids, since the preferred habitat of salmon in Norwegian coastal waters is the surface waters to a depth of $3 \mathrm{~m}$ (Holm et al. 1982, Heuch et al. 1995, Davidsen et al. 2008, Plantalech Manel-la et al. 2009). There is little comparable information for salmon in Scottish coastal waters, but it is thought that they also spend a high proportion of time in the upper layers (Malcolm et al. 2010).

The evolutionary biology and infestation dynamics of Lepeophtheirus salmonis should maximise opportunities for locating a suitable host. L. salmonis copepodids react positively to directional light and are attracted to areas of low pressure (Bron et al. 1993), so copepodids will tend to be in the upper surface waters during daylight. Heuch et al. (1995) observed a daily diel vertical migration, with copepodids sinking in the water column at night and rising at dawn. This migration is the opposite of wild salmonids, which appear to avoid the surface during daylight when not feeding, possibly to avoid predators (Fernö et al. 1995). These behaviours could increase the chance of L. salmonis copepodids encountering a suitable host as fish swim through a population of sinking (night-time) and rising (dawn) parasites (Holm et al. 1982, Dutil \& Coutu 1988, Fernö et al. 1995, Heuch et al. 1995). Bron et al. (1993) suggested that currents generated by salmon movement may stimulate sea lice in the water column to short bursts of speed and looping behaviour to enhance encountering host and settlement. The confinement of the sentinel fish to the cage and their more limited diurnal migration, if any, could affect the above interaction, particularly if the sentinel fish remain relatively sedentary. Alternatively, holding salmon in surface layers may ensure that, during daylight at least, there is a greater chance of interaction between host and parasite as more time is spent in the same environment.

Lice counts on the sentinel fish were proportional to fish surface area. This has been reported previously (O'Shea et al. 2006). It will therefore be important, when comparing results across studies, to be clear about the sizes of fish being considered. Here, the estimates of infestation pressure have been standardised to salmon of length $235 \mathrm{~mm}$, the median length of the fish in this study.

Infestation pressure increased rapidly from January 2007 and peaked in July and August 2007, with the highest abundance of 15.1 larval lice fish ${ }^{-1}$ observed in Cage 3 in July. Burdens of 20+ adult Lepeophtheirus salmonis fish $^{-1}$ on wild adult Atlantic salmon (Todd et al. 2006) and sea trout (Urquhart et al. 2008) have been recorded with no obvious detri- 
mental effects. However, fish exposed to the infestation pressures observed in July and August 2007 over a sustained period may accumulate burdens that have detrimental effects on the host. For example, infestation levels of 50 pre-adult and adult L. salmonis fish ${ }^{-1}$ on sea trout smolts (Bjørn \& Finstad 1997) and 30 to 50 chalimus fish $^{-1}$ on Atlantic salmon (Grimnes \& Jakobsen 1996) have been demonstrated to cause mortalities. A study of early returning postsmolt sea trout to the Shieldaig River recorded burdens of up to 69 L. salmonis fish ${ }^{-1}$ and, although there were no visible signs of damage, it is likely these burdens had caused the sea trout to return to freshwater after only a short period at sea (Pert et al. 2009).

Infestation pressure was higher in the cages nearer the River Shieldaig estuary. This is consistent with the results of McKibben \& Hay (2004), who found high numbers of planktonic Lepeophtheirus salmonis copepodids (up to $143 \mathrm{~m}^{-3}$ ) in the River Shieldaig estuary. It is also consistent with predictions from a sea lice dispersal model that sea lice densities will increase towards the Shieldaig River estuary due to wind forcing (Amundrud \& Murray 2009). Smolts migrating from the river would have experienced an estimated $61 \%$ reduction in infestation pressure as they travelled from Cage 3 to 2 (about $4 \mathrm{~km}$ ) and a further $34 \%$ reduction from Cage 2 to 1 (about $3 \mathrm{~km}$ ). However, with only 3 sentinel cages, it is not possible to estimate the infestation pressure experienced by a smolt integrated over its entire migration.

Louse abundance on the sentinel fish was correlated with gravid Lepeophtheirus salmonis counts from the 2 nearby farms over a wide range of time lags. These results are consistent with Penston et al. (2008b) and Penston \& Davies (2009), who found significant correlations between $L$. salmonis copepodid densities in the water column and gravid lice counts on nearby farms. However, when the de-trended data were examined, there was no evidence that directed changes in counts at the farms, brought about through treatment events, led directly to changes in infestation pressure at the sentinel cages. Marshall (2003) also found that lice treatments on a fish farm on Scotland's west coast impacted lice numbers on farmed salmon, but had no apparent effect on lice counts on wild salmonids.

Given the prevailing wind and currents (Fig. 1), and given the low number of returning salmonids in the Torridon system (Penston et al. 2008b), it is probable that the numbers of gravid lice on the fish farms were the dominant drivers of infestation pressure at the sentinel cages. Formally, however, the data provide no evidence of causality, only of asso- ciation. A relationship between the de-trended time series would be more likely with Farm 1, which was bigger and closer to the sentinel cages and had several lice treatments in 2007 (as did Farm 2), which might have provided large 'signals' that would be picked up at the sentinel cages. That no relationship was detected could be because any signal was dampened by the arrival of lice originating from Farm 2 or by patchiness in dispersal due to variation in wind direction and currents, or because lice densities rather than burdens were provided for the farms (the numbers of fish at the farms reduced during the study, so burdens cannot be inferred from densities). It is also possible that the numbers of fish sampled on the farms, while sufficient for management purposes, were insufficient to provide the precision required to detect such effects. Revie et al. (2007) showed that sampling fewer fish from more cages across a site gave a more precise estimate of the mean number of lice on the site. Torrissen et al. (2013) point out that studies often fail to recognise that correlations between sea lice counts on farms and wild fish impact/decline data do not necessarily imply cause and effect.

Sea lice dispersal models derived from systemspecific hydrodynamic or particle tracking models could aid interpretation by providing information on the relative contribution of each input location/farm to the infestation pressure at a specific site. However, while this might be feasible for short-term targeted studies, application to longer studies would demand considerable resource, unless there are persistent dispersal patterns or a predominant set of dispersal conditions in the system. Within the study area, the prevailing wind was predicted to distribute sea lice from both Farm 1 and Farm 2 in a similar pattern concentrating sea lice at the mouth of the Shieldaig River (Amundrud \& Murray 2009). However, it is unclear how this pattern will have differed in any given month, as there are insufficient field data to generate the relevant dispersal scenarios. Amundrud \& Murray (2009) show how changes in wind direction can change dispersal and localisation of sea lice.

Sentinel cages have the potential for providing an independent and standardised measure of lice pressure at fixed locations within the aquatic environment. The infestation pressure at any given location depends on the sea lice sources in the area, dispersal from them, and the survival and viability of sea lice delivered to that location. In a study by Bjørn et al. (2011), sentinel caged fish had significantly higher infestation levels in intensively farmed areas com- 
pared to a protected zone, even though there were no significant differences in gravid lice levels on farmed fish inside and outside the protected zone. This indicates that sentinel caged fish could provide a more informative measure of infestation pressure within a system than individual farm counts. How representative the infestation pressure on sentinel fish is of pressure on wild fish still requires some evaluation, given that wild fish move and given the spatial and temporal variability in sea lice dispersal and concentration (Amundrud \& Murray 2009). However, even with only a few locations, the resources required to deploy sentinel cages routinely would be considerable.

An alternative use for sentinel cage data is to validate predictions from sea lice dispersion models. The data presented here support predictions of areas of higher sea lice exposure made by the dispersion model of Amundrud \& Murray (2009), based on surface currents driven by the prevailing wind. Sentinel cage data will be used to validate dispersion models under development for the Loch Linnhe system, using field environmental and hydrodynamic data collected during sentinel cage deployment. Such dispersion models can identify dispersal patterns, dispersal distances, and areas of high infestation pressure under different conditions. This can contribute to more effective management strategies for sea lice control, thus helping operators to manage parasite populations, improve welfare for farmed fish and reduce any detrimental effects on wild salmonid populations.

Most of the Lepeophtheirus salmonis on the sentinel fish were copepodid or chalimus stages, so copepodids were the main infective life cycle stage in the water column. This indicates a local source. However, 12 pre-adult and 12 adult $L$. salmonis were also found on the sentinel fish. Due to the length of exposure, these must have come from the surrounding environment rather than developing on the fish following initial copepodid infestation (Johnson \& Albright 1991). This suggests that pre-adult and adult lice, although only a low proportion of the infective lice population, could be transported by wild fish or currents and infest salmonids some distance from the original source.

In conclusion, this study has used sentinel cages to estimate the infestation pressure at 3 fixed points along a salmonid migration route within a sea loch system over a 30 mo period. Infestation pressure was higher in cages nearer the head of the loch and the Shieldaig River estuary and correlated with gravid Lepeophtheirus salmonis counts from nearby farms.
However, there was no evidence that particular events at the farms led directly to changes in the abundance on sentinel fish. This suggests that, although aquaculture is a source of sea lice larvae to the Torridon system and therefore contributes to the infestation pressure on nearby wild salmonids, factors influencing infestation pressure at a given location and time are complex. Use of sentinel cages, shown here to be capable of detecting differences in infestation pressure at different locations, could contribute to a better understanding and evaluation of these factors and lead to improvements in management strategies.

Acknowledgements. We thank Kenny Livingston and Davy from HMMV 'Fram', Marine Scotland Science staff Carey Cunningham, Phillip MacLachlan, Roddy Paul, Kaisa Kantola, George MacLeod, Colin Stewart, Bill Leiper, Rebecca McIntosh, Chris Hall, Jim Raffel and Andy Moys. Lastly we thank the Loch Torridon Area Management Group for providing data that were invaluable to this study.

\section{LITERATURE CITED}

Amundrud TL, Murray AG (2009) Modelling sea lice dispersion under varying environmental forcing in a Scottish sea loch. J Fish Dis 32:27-44

Anonymous (2006) A code of good practice for Scottish finfish aquaculture. Scottish Salmon Producer's Organisation, Perth, p 1-22

Anonymous (2009) Shieldaig Project Review, June 2007June 2008. Marine Scotland Science, Aberdeen, p 1-18. Available at www.scotland.gov.uk/Uploads/Documents/ shieldaig_MSS_08v6.pdf (accessed June 28, 2012)

Bengtsen J, Asplin L, Bjørn PA, Sundby S (2012) The salinity tolerance of Lepeophtheirus salmonis larvae. In: Proceedings of the 9th International Sea Lice Conference, 21-23 May 2012, Institute of Marine Research, Bergen, p 23 (Abstract)

Bjørn PA, Finstad B (1997) The physiological effects of salmon lice infection on sea trout post smolts. Nord J Freshw Res 73:60-72

> Bjørn PA, Sivertsgård R, Finstad B, Nilsen R, Serra-Llinares RM, Kristoffersen R (2011) Area protection may reduce salmon louse infection risk to wild salmonids. Aquacult Environ Interact 1:233-244

Boxaspen K, Naess T (2000) Development of eggs and the planktonic stages of salmon lice (Lepeophtheirus salmonis) at low temperatures. Contrib Zool 69:51-55

Bricknell IR, Dalesman SJ, O'Shea B, Pert CC, Mordue Luntz AJ (2006) Effect of environmental salinity on sea lice Lepeophtheirus salmonis settlement success. Dis Aquat Org 71:201-212

Bron J, Sommerville C, Rae G (1993) Aspects of the behaviour of the copepodite larva of the salmon louse Lepeophtheirus salmonis (Krøyer, 1837). In: Boxshall GA, Defaye D (eds) Pathogens of wild and farmed fish: sea lice. Ellis \& Horwood, Chichester, p 125-140

Bruno DW, Stone J (1990) The role of saithe, Pollachius virens L., as a host for the sea lice, Lepeoptheirus salmo- 
nis Krøyer and Caligus elongatus Nordmann. Aquaculture 89:201-207

- Butler JRA (2002) Wild salmonids and sea louse infestations on the west coast of Scotland: sources of infection and implications for the management of marine salmon farms. Pest Manag Sci 58:595-608

Chambers CB, Ernst I (2005) Dispersal of the skin fluke Benedenia seriolae (Monogenea:Capsalidae) by tidal currents and implications for sea-cage farming of Seriola spp. Aquaculture 250:60-69

Costello MJ (2009) The global economic cost of sea lice to the salmonid farming industry. J Fish Dis 32:115-118

> Costelloe J, Costelloe M, Roche N (1995) Variation in sea lice infestation on Atlantic salmon smolts in Killary Harbour, West Coast of Ireland. Aquacult Int 3:379-393

> Davidsen JG, Plantalech Manel-la N, Økland F, Diserud OH and others (2008) Changes in swimming depths of Atlantic salmon Salmo salar post-smolts relative to light intensity. J Fish Biol 73:1065-1074

Diggle PJ (1990) Time series: a biostatistical introduction. Clarendon Press, Oxford

Dutil JD, Coutu JM (1988) Early marine life of the Atlantic salmon, Salmo salar, postsmolts in the northern gulf of St. Lawrence. Fish Bull US 86:197-212

Fernö A, Huse I, Juell JE, Bjordal A (1995) Vertical distribution of Atlantic salmon (Salmo salar L.) in net pens: tradeoff between surface light avoidance and food attraction. Aquaculture 132:285-296

Finstad B (2007) Final report for NFR-project no. 163869: The Hardangerfjord salmon lice project-2004-2007. Financed by Fiskeri-og Havbruksnæringens Forskningsfond (FHF), AquaNet-Canada, the Norwegian Research Council and the Norwegian Directorate for Nature Management. Available at www.marineharvest.com/PageFiles/1061/Hardanger\%20final\%20report.pdf (accessed June 29, 2012)

Finstad B, Bjørn PA, Hvidsten NA (2000) Laboratory and field investigations of salmon lice [Lepeophtheirus salmonis (Krøyer)] infestation on Atlantic salmon (Salmo salar L.) post-smolts. Aquacult Res 31:795-803

- Gaines SD, Bertness M (1993) The dynamics of juvenile dispersal: why field ecologists must integrate. Ecology 74 : 2430-2435

Gillibrand PA, Amundrud TL (2007) A numerical study of the tidal circulation and buoyancy effects in a Scottish fjord: Loch Torridon. J Geophys Res 112:1-22

Grimnes A, Jakobsen PJ (1996) The physiological effects of salmon lice (Lepeophtheirus salmonis Krøyer) infection on post smolt of Atlantic salmon (Salmo salar). J Fish Biol 48:1179-1194

> Hamre LA, Eichner C, Caipang CMA, Dalvin ST and others (2013) The salmon louse Lepeophtheirus salmonis (Copepoda: Caligidae) life cycle has only two chalimus stages. PLoS ONE 8(9):e73539

> Heuch PA, Karlsen HE (1997) Detection of infrasonic water oscillations by copepodids of Lepeophtheirus salmonis (Copepoda: Caligidae). J Plankton Res 19:735-747

$>$ Heuch PA, Parsons A, Boxaspen K (1995) Diel vertical migration: a possible host-finding mechanism in salmon louse (Lepeophtheirus salmonis) copepodids? Can J Fish Aquat Sci 52:681-689

Holm S (1979) A simple sequentially rejective multiple test procedure. Scand J Stat 6:65-70

Holm M, Huse I, Waatevik E, Deving KB, Aure J (1982) Behaviour of Atlantic salmon smolts during seaward migra- tion. I. Preliminary report on ultrasonic tracking in a Norwegian fjord. ICES CM 1982/M:7. ICES, Copenhagen

Hull MQ, Pike AW, Mordue AJ, Rae GH (1998) Patterns of pair formation and mating in an ectoparasitic caligid copepod Lepeophtheirus salmonis (Krøyer 1837): implications for its sensory and mating biology. Philos Trans $\mathrm{R}$ Soc Lond B 353:753-764

Johannessen A (1978) Early stages of Lepeophtheirus salmonis (Copepoda, Caligidae). Sarsia 63:169-176

$>$ Johnson SC, Albright LJ (1991) Development, growth, and survival of Lepeophtheirus salmonis (Copepoda, Caligidae) under laboratory conditions. J Mar Biol Assoc UK 71:425-436

Johnson SC, Treasurer JW, Bravo S, Nagasawa K, Zbigniew $\mathrm{K}$ (2004) A Review of the impact of parasitic copepods on marine aquaculture. Zool Stud 43:229-243

Kabata Z (2003) Copepods parasitic on fishes. In: Crothers JH, Hayward PJ (eds) Synopses of the British Fauna, (new series) No 47. Field Studies Council, Shrewsbury, p 42-74

Losos CJC, Reynolds JD, Dill LM (2010) Sex-selective predation by three spine sticklebacks on sea lice: a novel cleaning behaviour. Ethology 116:981-989

Malcolm IA, Godfrey J, Youngson AF (2010) Review of migratory routes and behaviour of Atlantic salmon, sea trout and European eel in Scotland's coastal environment: implications for the development of marine renewables. Scott Mar Freshw Sci Vol 1 No 14. Available at www.scotland.gov.uk/Resource/Doc/295194/0111162. pdf (accessed June 29, 2012)

Marshall S (2003) The incidence of sea lice infestations on wild sea trout compared to farmed salmon. Bull Eur Assoc Fish Pathol 23:72-79

McBeath AJA, Penston MJ, Snow M, Cook PF, Bricknell IR, Cunningham CO (2006) Development and application of real-time PCR for specific detection of Lepeophtheirus salmonis and Caligus elongatus larvae in Scottish plankton samples. Dis Aquat Org 73:141-150

McCulloch CE, Searle SR (2001) Generalized, linear, and mixed models. John Wiley \& Sons, New York, NY

McKibben MA, Hay DW (2004) Distributions of planktonic sea lice larvae Lepeophtheirus salmonis in the intertidal zone in Loch Torridon, Western Scotland in relation to salmon farm production cycles. Aquacult Res 35: 742-750

McVicar AH, Sharp LA, Pike AW (1993) Infectious diseases of Scottish sea trout and salmon. In: Shelton RGJ (ed) Problems with sea trout and salmon in the Western Highlands. Atlantic Salmon Trust Series Vol 17. Atlantic Salmon Trust Pitlochry, p 48-60

Middlemas SJ, Raffell JA, Hay DW, Hatton-Ellis M, Armstrong JD (2010) Temporal and spatial patterns of sea lice levels on sea trout in western Scotland in relation to fish farm production cycles. Biol Lett 6:548-551

Middlemas SJ, Fryer RJ, Tulett D, Armstrong JD (2012) Relationship between sea lice levels on sea trout and fish farm activity in western Scotland. Fish Manag Ecol 20:68-74

Moksnes PO, Wennhage H (2001) Methods for estimating decapod larval supply and settlement: importance of larval behavior and developmental stage. Mar Ecol Prog Ser 209:257-273

O'Shea B, Mordue-Luntz AJ, Fryer RJ, Pert CC, Bricknell IR (2006) Determination of the surface area of a fish. J Fish Dis 29:437-440 
Penston MJ, Davies IM (2009) An assessment of salmon farms and wild salmonids as sources of Lepeophtheirus salmonis (Krøyer) copepods in the water column in Loch Torridon, Scotland. J Fish Dis 32:75-88

Penston MJ, McKibben MA, Hay DW, Gillibrand PA (2004) Observations on open-water densities of sea lice larvae in Loch Shieldaig, Western Scotland. Aquacult Res 35: 793-805

Penston MJ, Millar CP, Davies IM (2008a) Spatial and temporal distribution of Lepeophtheirus salmonis (Krøyer) larvae in a sea loch containing Atlantic salmon, Salmo salar L., farms on the north-west coast of Scotland. J Fish Dis 31:361-371

Penston MJ, Millar CP, Davies IM (2008b) Reduced Lepeophtheirus salmonis larval abundance in a sea loch on the west coast of Scotland between 2002 and 2006. Dis Aquat Org 81:109-117

Penston MJ, McBeath AJA, Millar CP (2011) Densities of planktonic Lepeophtheirus salmonis before and after an Atlantic salmon farm relocation. Aquacult Environ Interact 1:225-232

Pert CC, Raffell J, Urquhart K, Weir SJ, Kantola KMH, Bricknell IR (2009) The pathogen burden of early returning sea trout (Salmo trutta L.) infected with Lepeophtheirus salmonis, in the river Shieldaig, Scotland. Bull Eur Assoc Fish Pathol 29:210-216

> Piasecki W (1996) The developmental stages of Caligus elongatus von Nordmann, 1832 (Copepoda: Caligidae). Can J Zool 74:1459-1478

Piasecki W, MacKinnon BM (1995) Life cycle of a sea louse, Caligus elongatus von Nordmann, 1832 (Copepoda, Siphonostomatoida, Caligidae). Can J Zool 73:74-82

Pike AW, Wadsworth S (1999) Sealice on salmonids: their biology and control. Adv Parasitol 44:233-337

Plantalech Manel-la N, Thorstad EB, Davidsen JG, Økland F, Sivertsgård R, McKinley RS, Finstad B (2009) Vertical movements of Atlantic salmon postsmolts relative to measures of salinity and water temperature during the first phase of the marine migration. Fish Manag Ecol 16: $147-154$

Revie CW, Hollinger E, Gettinby G, Lees F, Heuch PA (2007) Clustering of parasites within cages on Scottish and Norwegian salmon farms: alternative sampling strategies illustrated using simulation. Prev Vet Med 81: 135-147

Ritchie G (1997) The host transfer ability of Lepeophtheirus

Editorial responsibility: Bengt Finstad,

Trondheim, Norway salmonis (Copepoda: Caligidae) from farmed Atlantic salmon, Salmo salar L. J Fish Dis 20:153-157

Schram TA (1993) Supplementary descriptions of the developmental stages of Lepeophtheirus salmonis (Krøyer, 1837) (Copepoda: Caligidae). In: Boxshall GA, Defaye D (eds) Pathogens of wild and farmed fish: sea lice. Ellis Horwood, Chichester, p 30-50

Sollid SA, Lorz HV, Stevens DG, Reno PW, Bartholomew JL (2004) Prevalence of Myxobolus cerebralis at juvenile salmonid acclimation sites in northeastern Oregon. N Am J Fish Manage 24:146-153

Stien A, Bjørn PA, Heuch PA, Elston DA (2005) Population dynamics of salmon lice Lepeophtheirus salmonis on Atlantic salmon and sea trout. Mar Ecol Prog Ser 290: 263-275

Todd CD, Whyte BDM, MacLean JC, Walker AM (2006) Ectoparasitic sea lice (Lepeophtheirus salmonis and Caligus elongatus) infestations of wild, adult, one seawinter Atlantic salmon Salmo salar returning to Scotland. Mar Ecol Prog Ser 328:183-193

Torrissen O, Jones S, Asche F, Guttormsen A and others (2013) Salmon lice-impact on wild salmonids and salmon aquaculture. J Fish Dis 36:171-194

Tully O (1989) The succession of generations and growth of the caligid copepod Caligus elongatus and Lepeophtheirus salmonis parasitising farmed Atlantic salmon smolts (Salmo salar L.). J Mar Biol Assoc UK 69:279-287

Tully O, Whelan KF (1993) Production of nauplii of Lepeophtheirus salmonis (Krøyer) (Copepoda: Caligidae) from farmed and wild salmon and its relation to the infestation of wild sea trout (Salmo trutta L.) off the west coast of Ireland in 1991. Fish Res 17:187-200

> Urquhart K, Pert CC, Kilburn K, Fryer RJ, Bricknell IR (2008) Prevalence, abundance, and distribution of Lepeoptheirus salmonis (Krøyer, 1837) and Caligus elongatus (Nordmann, 1832) on wild sea trout Salmo trutta L. ICES J Mar Sci 65:171-173

Vøllestad LA, Hirst D, L'Abe'e-Lund JH, Armstrong JD, MacLean JC, Youngson AF, Stenseth NC (2009) Divergent trends in anadromous salmonid populations in Norwegian and Scottish rivers. Proc R Soc Lond B Biol Sci 276:1021-1027

Wootten R, Smith JW, Needham EA (1982) Aspects of the biology of the parasitic copepods Lepeophtheirus salmonis and Caligus elongatus on farmed salmonids and their treatment. Proc R Soc Edinb B Biol Sci 81:185-197

Submitted: January 9, 2013; Accepted: February 11, 2014 Proofs received from author(s): March 14, 2014 